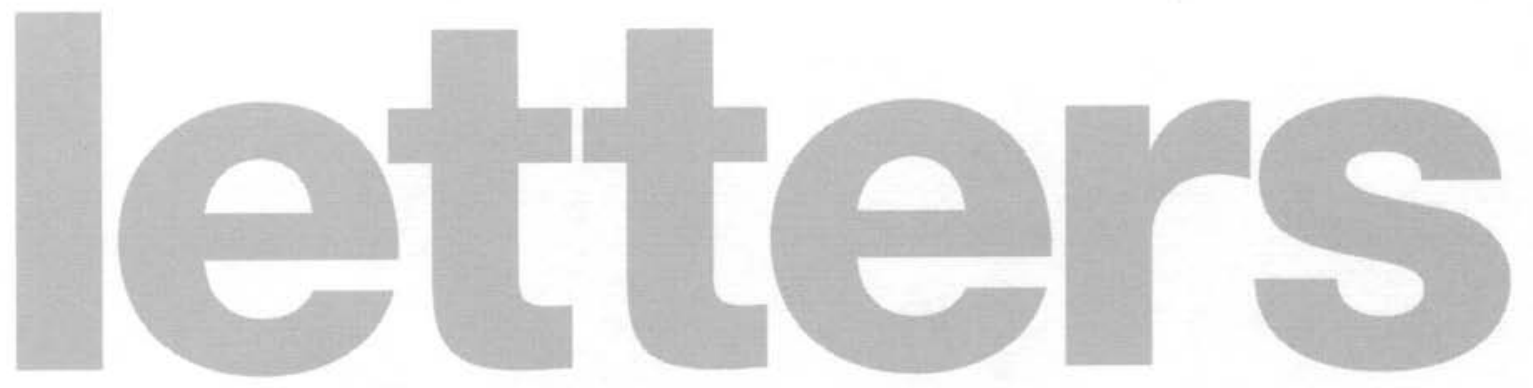

\section{The two Scharouns}

Sir: Between 1963 and 1971 I was the project architect for Scharoun's school in Marl and am pleased that the dilemma of the actual use of this building has now become a serious matter of discussion (arq vol.1: nos.1 and 2). William Fawcett's conclusion that 'the key to Scharoun's work is some kind of generative design algorithm or grammar' (a field with which I have been involved for several years) was of particular interest to me.

The adaptation of his 'Darmstadt programme' to the situation in Mart was explained by Scharoun in Bauten Entwürfe Texte, Herausgegeben von Peter Pfankuch, Schriftenreihe der Akademie der Künste Band 10, Berlin 1974/93, pp.262. A particular aspect of this, based on the assumed educational requirements of a region such as Marl, lies in the design of the workshops and other special rooms. This seems to have worked well and four years ago I found these sections, together with the audience hall, in use The rest of the school was more or less abandoned, exhibiting signs of vandalism and decay, apocalyptic in appearance. This is the manifestation of what has not been working in practice: Scharoun's main 'educational' concern, the correspondence between architectural shape and stages of psychological development, as explained by Friedrich Mebes. In this regard, the school has only occasionally been used as originally intended. This was confirmed by the officials and personnel involved, with whom I have also discussed the first two of the following factors: - the reorganisation of the educational sector which conflicted with the requirements of the original brief. - demographic changes which made many school buildings in Marl and elsewhere in Europe redundant. - the fact that Scharoun was commissioned to build that school because of his prestige, and not because any of the responsible authorities was seriously interested in Scharoun's particular ideas and intentions about school building.

The dilemma of the actual use of the school became apparent while it was still under construction. At that stage, I asked Scharoun: 'What shall we do? This building is practically unusable'. Hesitatingly he nodded: 'Yes, I know ...' But he did not give me a direct answer. On another occasion I heard him defending himself: 'I have the chance now to build some real examples in terms of einem Bild [an image] and einem Zeichen [a sign]. To do that properly, that's what is left for me to do'. He did not use the word Gestalt, which contradicts his own 'official' language in the texts of the kind I have referred to.

In fact, there were two Scharouns, the real Scharoun and, to put it hyperbolically, the face-value Scharoun. The key to Scharoun's work, 'some kind of a design algorithm', as William Fawcett suggests, is closer to the real, the 'living' Scharoun, because it is a key to the understanding of the language and the nature of the 'mental design machine' driven by 'images' and 'signs' and not by verbalised programmes alone.

The school in Mart is certainly adaptable, but not in terms of Scharoun's ideas as demonstrated at Darmstadt. In that regard its 'hyperfunctionalism' is close to the kind of inexorable systems of 'ceremonial games' discussed by e.g. Roland Barthes in Sade, Fourier, Loyola.
I have written about Scharoun, Marl and algorithmic design structures in the Italian journal Housing (no.6. 1994) and the first results of an algorithmic description of Scharoun's design method (not of schools but of housing) were presented by me at the 'Werkschau Hans Scharoun' exhibition at the Akademie der Künste, Berlin in 1993. Meanwhile, my investigations have been addressed to another audience: the AID (Artificial Intelligence in Design) community. The algorithm touched on only cursorily in Housing is discussed more fundamentally in a paper to be presented to the AID' 96 conference in Palo Alto this June. The other audience however is in 'architectural theory'. So far, I have found little serious discussion of this subject in the literature of either field. There seems to be no organ for it apart from Archithèse. Perhaps arq can, taking up William Fawcett's final remark, open the way for this.

Michael Hellgardt

Amsterdam

Michael Hellgardt practises as an architect and may be contacted at Prinsengracht 151 , 1015 DR Amsterdam. Email michae/Ohellgar.iaf.nI

\section{Ideas, not journalism}

Sir: As a former Editor of Scroope (the Cambridge architecture journal) and now a practising architect and teacher, I would like to comment on Colin Davies' review of architecture school journals (arq no.2, vol.1).

I disagree in principle with the view that these publications should concern themselves with 'journalism and criticism' of recent buildings which 1 suggest is adequately dealt with in professional publications. Not only is this their specified agenda but they also enjoy far greater resources, a 
wider readership and a greater frequency of publication than school magazines, which invariably allows them to report on recent buildings more effectively. It does however raise an issue which I consider central to architectural education, namely interpretation.

The view taken by successive Editors of Scroope is that the publication should provide a platform for both student theses and the wisdom of invited contributors as a means of opening up a debate both within the school and on a broader horizon. It is dealing with 'idea' as an interpretative vehicle and not journalistic recording of events. Indeed, as Peter Carl (a teacher at Cambridge) recently discussed at an Architectural Association lecture, architectural debate within this country is unfortunately confined to the schools. The role, as I see it, of school publications is therefore to make concrete such debate - of 'ideas' and to represent it to the world of praxis within which most architects find themselves.

Articles in Scroope therefore draw on many subjects, of which buildings are one, as vehicles for interpretation of 'idea', as a means of exploring their relevance to today's situation and what architecture could be.

Alun Jones

\section{London}

Alun Jones works for Caruso St. John and teaches at the Architectural Association School of Architecture

\section{Curiously contemporary} Sir:Jeffrey Cook and Tanis Hinchcliffe (arq vol.1: no.2) propose that the Natural History Museum in South Kensington, completed in April 1881, '... may indeed be ... a model again for a future of passive and low energy buildings'.

The authors' account, and the correspondence they have exhumed, suggests that Alfred Waterhouse and his engineer Wilson Phipson assembled, together, quite a sophisticated strategy. One suspects that it was not unsuccessful. The volumes are large, with six metre ceiling heights, and periodically incorporate the volume of the roof profile, and exploit the ridges as extracts. The building was intended to be naturally lit, certainly in the overheating season, and internal heat gains from lighting devices would be restricted. Internal temperatures in midwinter were to be kept to a cool 13 to $14^{\circ}$. A Relative Humidity would be maintained at a level to reduce the danger of the long term desiccation of exhibits and guards.

Furthermore the Museum is heavily constructed. Was Waterhouse drawn to attempt a radical transformation of the Rundbogenstil in its GermanRomanesque manifestation, partly because he had been affected by the very stable but charged environments he had experienced within the originals?

The dedicated voids and routes for the delivery and removal of air are of a size, necessarily, to enter into the primary configuration of the building, to the architect's obvious enjoyment. In this respect Cook and Hinchcliffe might have a point. Why not continue to exploit the stack effect? Perhaps its necessanily vertical manifestation is thought to be mildly distasteful because it collides with three apparently important leitmotivs of the twentieth century 'Will to Form, horizontality' and 'dematerialisation'.

The correspondence sounds curiously contemporary. There is a prediction of likely performance. How on earth did Phipson know how to predict the likely conditions? What were the consequences of being judged to have been in breach of contract in the 1880s. One can only imagine that they were quite unpleasant. One presumes that the designers were working on the basis of a substantial body of collective practical experience. Much of this seems to have been lost. If the authors are correct, then this is highly regrettable. There is a deep anxiety about the builder's work elements being of the correct form, and that the client did not arbitrarily propose an alternative system towards the conclusion of the construction drawings. This anxiety is rewarded by a compliment from the environmental engineer that the architect has understood the environmental strategy and it is fully incorporated into the stuff of the building.

The authors' analysis is certainly of sufficient interest to ask if the original environmental control strategy actually worked to some extent. Might one encourage Cook and Hinchcliffe to pursue their researches further, and in the absence of contemporary evidence, engage in a little simulation of one or two of the principal spaces, as they were originally envisaged to operate? Their conclusion may be even more significant than even they suspect. Alan Short London

Alan Short, an architect, is a partner in Short Ford Letters, should be typed doublespaced and sent to Peter Carolin, Architectural Research Quarterly, c/o University of Cambridge Department of Architecture, 1 Scroope Terrace, Cambridge, CB2 1PX, faxed to +44 (0) 1223 332960 , or e-mailed to pc207@hermes.cam.ac.uk The editor reserves the right to shorten letters. letters 